\title{
REINTERPRETASI RELASI TUHAN DAN MANUSIA SYED MUHAMMAD NAQUIB AL-ATTAS
}

\author{
Tri Arwani Maulidah \\ An-Najiyah Sidosermo Surabaya, Indonesia \\ E-mail: niemaulidah@gmail.com
}

\begin{abstract}
The article attempts to reanalyze the concept of God, human, and their relation. God, in Islam, is The One, The Life, The Eternal, and The Endless. His Oneness is absolute, but His Absoluteness is unlike the absoluteness of the universe. God is transcendent and immanent at the same time. Al-Attas distinguishes the concept of God as Rabb and God as Iläh. Human, to al-Attas, is spirit and organism, and body and soul. The organismic side of human beings along with their five senses functions to help them living in the world. The spiritual dimension of human beings, on the other side, has an ability to formulate a set of meanings which involve assessment, differentiation, and explanation. When we observe the relation of God and human from the concept of tawhid ulübiyah and tawhid rubübiyah we will find two interrelated role of human, namely the role as God's servant and the role as God's representative and mandate (khalifah) on the earth. These two roles are inseparable. Al-Attas argues that separation of the two will create imbalance personality of the human. It will subsequently jeopardize their existence and the earth they live on.
\end{abstract}

Keywords: Relation; tawhìd ulühìyab; tawhīid rubübìyah.

Abstrak: Artikel ini menganalisis relasi Tuhan dan manusia dalam perspektif Syed Muhammad Naquib Al-Attas. Tuhan, dalam Islam, adalah Yang Maha Esa, Maha Hidup, Maha Kekal, dan Maha Abadi. Keesaan-Nya adalah absolut, tetapi keabsolutan-Nya tidak sama dengan keabsolutan alam semesta. Tuhan itu transenden dan imanen. Ia membedakan konsep Tuhan sebagai Rabb dan sebagai Iläh. Baginya, manusia adalah roh dan organisme, dan tubuh dan jiwa. Sisi organisme manusia bersama dengan panca indra mereka berfungsi untuk membantu mereka hidup di dunia. Dimensi spiritual manusia, di sisi lain, memiliki kemampuan untuk merumuskan serangkaian makna yang melibatkan penilaian, diferensiasi, dan penjelasan. Dalam hubungan keduanya dari konsep tawhịd ulühiyah dan tawbìd rubübiyah kita akan menemukan dua peran manusia yang saling terkait, yaitu peran sebagai hamba Tuhan dan peran sebagai wakil dan khalifah di bumi. Kedua peran ini tidak dapat dipisahkan. Al-Attas berpendapat pemisahan keduanya akan menciptakan ketakseimbangan kepribadian manusia dan ini akan membahayakan eksistensi mereka dan bumi tempat mereka tinggal.

Kata Kunci: Relasi; tawhịd ulühìyab; tawhìd rubübīyah. 


\section{Pendahuluan}

Dalam sejarah perkembangan manusia, konsep ketuhanan telah melalui berbagai perkembangan. Konsep Tuhan dalam sejarah manusia terkait erat dengan kepercayaan manusia terhadap hal-hal yang bersifat abstrak atau gaib. Dalam konteks hubungan antara Tuhan dan manusia terdapat ragam teori, di antaranya monoteisme, deisme, panteisme, dan panenteisme. Pada agama-agama SemitikIslam, Yahudi, dan Kristen-teori monoteisme merupakan teori yang paling tepat untuk mengarakteristikkan paham Tuhan. ${ }^{1}$ Tuhan dalam paham ini dipandang sebagai pencipta yang transenden dan absolut. Tuhan adalah asal dan tujuan segenap ciptaan. ${ }^{2}$

Sedangakan dalam paham deisme yang muncul pada masa Abad Pencerahan, Tuhan hanya dipercaya sebagai Pencipta. Sedangkan relasi Tuhan dengan ciptaan-Nya sekadar penciptaan. Dengan selesainya penciptaan karya Tuhan selesai. ${ }^{3}$ Tuhan menciptakan dunia beserta isinya, akan tetap setelah itu, Tuhan tidak turut-campur dalam jalannya dunia dan kehidupan makhluk di dalamnya termasuk manusia. Tuhan diibaratkan seperti seorang tukang jam yang canggih. Tukang itu membuat jam, mengatur jalan jam dengan mesin dan setelah itu membiarkan jam itu hidup dan berjalan menurut kecepatan dan irama yang sudah diaturnya. ${ }^{4}$

Dalam paham panteisme, Tuhan tidak memliki perbedaan dengan ciptaannya. Tuhan dan ciptaannya adalah sama. ${ }^{5}$ Terdapat perbedaan antara panteisme Barat dan panteisme Timur. Jika panteisme di Barat mengatakan bahwa segala sesuatu adalah Tuhan, panteisme Timur mengatakan bahwa segala sesuatu ada dalam Tuhan. Hal ini berarti bahwa Tuhan dan makhluk-makhluk ciptaan menjadi satu seperti perumpamaan badan dan jiwa dalam dri manusia, meskipun ciptaan bergantung dan berbeda dengan Tuhan. ${ }^{6}$ Dalam Islam panteisme biasa disebut dengan waḥdat al-wujūd (kesatuan wujud). Salah satu filsuf Muslim yang populer dengan paham waḥdat al-wujūd adalah Ibn 'Arabī.

1 Louis Leahy, Dunia, Manusia, dan Tuhan: Antologi Pencerahan Filsafat dan Teologi (Yogyakarta: Kanisius, 2008), 70.

2 Ibid., 71.

3 Tom Jacobs SJ, Paham Allah dalam Filsafat, Agama-agama dan Teologi (Yogyakarta: Kanisius, 2006), 72-73.

4 A. M. Hardjana, Penghayatan Agama: Yang Otentik dan Tidak Otentik (Yogyakarta: Kanisius, 1993), 35.

${ }^{5}$ Harry Hamaersma, Pintu Masuk Dunia Filsafat (Yogyakarta: Kanisius, 2008), 27.

${ }^{6}$ Mariasusai Dhavamony, Fenomenologi Agama (Yogyakarta: Kanisius, 1995), 141. 
Terdapat perbedaan antara panteisme dan wahdat al-wujüd. Dalam panteisme alam adalah Tuhan dan Tuhan adalah alam. Dalam wabdat al-wujüd, alam bukanlah Tuhan melainkan bagian dari Tuhan. ${ }^{7}$

Sedikit berbeda dengan panteisme yang menyatakan semua adalah Tuhan. Paham ini menekankan bahwa Tuhan pada aspek terbatas, berubah, mengatur alam, dan bekerja sama dengan alam untuk dapat meraih kesempurnaan daripada memandang Tuhan sebagai Zat yang tidak terbatas, menguasai alam, dan tidak berubah. Panenteisme meyakini bahwa Tuhan memiliki dua kutub, yakni potensi dan aktual. Kutub potensi berarti bahwa Tuhan abadi, tidak berubah, dan transenden. Sedangkan kutub aktual berarti bahwa Tuhan yang berubah, tidak abadi, dan imanen. Tuhan dalam pandangan panenteisme bersifat imanen dan transenden. ${ }^{8}$

Konsep Tuhan dan relasinya dengan manusia dengan alam dan kebudayaan ini juga banyak diulas oleh akademisi Muslim, satu di antaranya Syed Muhammad Naquib Al-Attas (1. 1931). Ia membangun worldview Islam dalam menjawab problem ontologis ini. Baginya, dalam Islam, telah dijelaskan dalam ayat-ayat al-Qur'ān mengenai hubungan manusia dengan Tuhannya, mulai dari penciptaan hingga eksistensi manusia khusunya sebagai khalifah fi al-ard. Umumnya relasi ini dapat diilustrasikan sebagai relasi antara pencipta dengan makhluknya. Tuhan adalah pencipta dan manusia adalah makhlunyā Antara pencipta dengan makhluk senantiasa terjalin komunikasi, baik bersifat verbal, lingustik atau non-linguistik. Karena Tuhan adalah pencipta dan pemelihara manusia, sepatutnya ia mengabdi kepadaNya. Selain itu, dalam al-Qur'ān dijelaskan bahwa Tuhan bersifat etis melalui asmä' al-husnā. Sifat dan tindakan Tuhan ini memberikan pengertian bahwa manusia diharapkan dapat memiliki sifat etis dan dapat merespons tindakan Tuhan dengan cara yang etis pula.

\section{Konsep Tuhan Syed Naquib Al-Attas}

Konsep mengenai Tuhan, bagi Syed Naquib Al-Attas, adalah salah satu konsep utama yang mendasari paradigma agama Islam. Konsep Tuhan dalam Islam berbeda dengan konsep pada agama lain ataupun dengan tradisi filsafat, budaya, dan peradaban lainnya. Perbedaan

\footnotetext{
7 M. Baharuddin, "Konsepsi Ketuhanan Sepanjang Sejarah Manusia", Jurnal alAdyan, Vol. IX, No. 1 (2014), 50.

8 Amsal Bakhtiar, Filsafat Agama: Wisata Pemikiran dan Kepercayaan Manusia (Jakarta: Rajawali Pers, 2009), 100.
} 
pandangan mengenai konsep Tuhan ini berawal dari perbedaan memahami wujud (eksistensi).

Wujud merupakan pembahasan mengenai metafisika. Pembahasan mengenai metafisika dalam Islam harus bersumber dari wahyu, bukan dari spekulasi filsuf yang dirumuskan dari pengamatan dan data pengalaman indrawi, atau hanya terbatas oleh hal-hal yang terlihat oleh mata atau materi yang dilihat. Hal ini dikarenakan pandangan Islam tentang wujud tidak hanya terbatas kepada alam fisik saja ataupun ragam aspek yang berhubungan langsung dengan manusia dalam sejarah, sosial, politik, ataupun budaya. Wujud dalam Islam mencakup aspek dunia dan akhirat. Aspek dunia harus dihubungkan dengan cara yang mendalam kepada aspek akhirat yang memiliki signifikasi yang terakhir dan final. wujud juga mencakup entitasentitas materi dan non-materi, rasional dan supra-rasional. ${ }^{9}$

Menurut al-Attas, wujud tidak hanya mental saja tapi juga nyata. Eksistensi bukan hanya entitas metal yang tidak terkait dengan realitas dunia eksternal, tetapi juga nyata. Ada concept of exixtence dan reality of existence. ${ }^{10} \mathrm{Al}$-Attas menyatakan sesuatu itu adalah esensinya. Baginya, tidak ada perbedaan nyata antara esensi dan eksistensi. Perbedaan keduanya hanya ada dalam pikiran, bukan kenyataan. Eksistensi adalah wujud nyata atau sesuatu yang muncul dari esensi-esensi dan apa yang secara mental 'esensi-esensi' atau mähìyah pada kenyataannya adalah aksiden ('ard) kepada eksistensi. Wujud adalah the finding of truth in existence, dan alam hanya aksiden terhadap Tuhan. ${ }^{11}$

Al-Attas membedakan antara esensi (essense) dan mähìah (quiddity). Realitas sesuatu disebut dengan esensi. ${ }^{12}$ Sedangkan māhijyah dalam makna yang umum adalah esensi (quidity in this general sense what we mean by essence). ${ }^{13}$ Al-Attas mendeskripsikan esensi sebagai eksistensi dan mähìah, akan tetapi mähìah bukanlah realitas sesuatu. Realitas sesuatu adalah wujud (eksistensi). Oleh sebab itu, Tuhan adalah Eksistensi Mutlak. Alam semesta merupakan manifestasi (tajalli) dari Eksistensi-

9 Syed Muhammad Naquib Al-Attas, Prolegomena to the Metaphysic of Islam: An Exposition of the Fundamental Elements of Worldview of Islam (Kuala Lumpur: ISTAC, 1995), 1-2.

${ }^{10}$ Ibid., 217-218.

11 Ibid., 183.

12 Ibid., 233.

${ }^{13}$ Ibid., 234. 
Nya. ${ }^{14}$ Hal ini dapat dirujuk pada Q.S. al-Qașaș [28]: 88, Q.S. alBaqarah [2]: 115, Q.S. al-A'rāf [07]: 172.

Al-Attas menjelaskan Tuhan dalam Islam adalah Esa, hidup, kekal dan abadi. Eksistensi-Nya adalah Wujud Mutlak dari esensi-Nya. Satusatunya Wujud yang mähiyah-Nya sama dengan eksistensi-Nya. Keesaaan-Nya adalah Mutlak, yang kemutlakannya tidak seperti mutlaknya alam semesta. Tuhan juga bersifat transenden, tetapi transenden yang tidak membatasi Tuhan untuk menjadi omnipresent. Tuhan juga imanen, tetapi imanen yang berbeda dengan apa yang dipahami oleh paham panteisme. Esensi Tuhan adalah Mutlak, Kekal, dan Maha Sempurna. Tuhan Maha Hidup, Kuat, Mengetahui, Berkehendak, Mendengar, Melihat, dan Berbicara dengan atributatribut-Nya, yakni hidup, kekuatan, ilmu, kehendak, pendengaran, penglihatan, dan perkataan-Nya. Kebalikan dari ini adalah mustahil. ${ }^{15}$

Konsep Tuhan dalam Islam juga berbeda dengan konsep Tuhan menurut Aristotelian dan Platonis. Dalam pandangan Aristotelian, Tuhan adalah penggerak utama (The Mover unmover) dan satu-satunya bentuk murni. Tuhan adalah penggerak yang menyebabkan gerak abadi. Dia tidak digerakkan, karena bebas dari materi, sehingga Tuhan tidak turut campur dalam aktivitas dunia dan manusia. ${ }^{16}$ Karena jika Tuhan bergerak, maka Dia terbatas ruang dan waktu. Jika terbatas ruang dan waktu, maka Tuhan terbatas dan tidak berkuasa. Hal ini tidak mungkin, karena bertentangan dengan pandangan Islam. Tuhan adalah penggerak utama, tetapi gerakan Tuhan tidak sama dengan gerakan makhluk yang terbatas ruang dan waktu.

Plotinus memiliki pandangan berbeda dari Aristoteles mengenai konsep Tuhan. Tuhan dalam pandangan Plato adalah Realitas Hakiki transenden dan sempurna. Keberadaan-Nya tercermin dalam realitas dunia semu. ${ }^{17}$ Kekuasaan dan tanggung jawab Tuhan hanya terbatas terhadap hal-hal yang baik. Plato juga menamakan Tuhannya dengan sebutan The God. Tuhan tidak melakukan keburukan terhadap alam

\footnotetext{
${ }^{14}$ Ibid., 234.

15 Ibid., 12.

16 Aristoteles menggunakan beberapa sebutan untuk Sang Wujud, seperti The Prime Mover, The First Cause, dan The Form of Forms. Aristoteles menegaskan bahwa aktivitas Tuhan hanyalah berpikir dan berkontemplasi. Oleh sebab itu tidak ada aktivitas yang lebih tinggi daripada berpikir dan merenung. Amroeni Drajat, Subarwardi: Kritik Falsafah Paripatetike (Yogyakarta: LKiS, 2005), 98.

17 Kumara Ari Yuana, 100 Tokoh Filsuf Barat dari Abad 6 SM-Abad 21 yang Menginspirasi Dunia Bisnis (Yogyakarta: Andi Offset, 2010), 68.
} 
semesta ataupun manusia karena keburukan adalah suatu kelemahan Tuhan. ${ }^{18}$ Pandangan Plato ini mempengaruhi pandangan mazhab Mu'tazilah tentang sifat adil Tuhan. Tuhan tidak melakukan keburukan terhadap manusia karena perbuatan tersebut merupakan suatu kelemahan, bahkan bagi sebagian pendukung $\mathrm{Mu}^{6}$ tazilah Tuhan tidak dapat melakukan keburukan karena dapat mengurangi kesempurnaan Tuhan yang Maha Sempurna. ${ }^{19}$

Tuhan dalam pandangan Plato adalah "Esa". Makna "Esa" menurut Plato berbeda dengan makna "Esa" dalam Islam. Dalam pandangan Plato dari yang Esa itu melimpahkan akal pertama (al-'aql al-awwal), kemudian akal pertama melahirkan jiwa (al-nafs al-kulliyah), lalu muncul alam (al-hayülä). Teori penciptaan ini kemudian disebut dengan emanasi (fayd); alam terpancar melalui Tuhan sebagaimana cahaya yang keluar dari matahari. ${ }^{20}$ Dalam teori emanasi, Tuhan tidak menciptakan semesta dari ketiadaan melainkan dari materi pertama.

Berbeda dengan pandangan Aristoteles dan Plato, Tuhan dalam Islam adalah unik. Tuhan bersifat transenden sekaligus imanen. Akan tetapi transendensi dan imanensi Tuhan dalam Islam berbeda dengan pandangan-pandangan sekuler. Pandangan sekuler yang menyamakan konsep Tuhan dalam level transenden tidak tepat. Karena pada level esoteris, setiap agama memiliki konsep Tuhan yang eksklusif. Pemikiran seperti ini menurut al-Attas, bukanlah agama melainkan pengalaman-pengalaman individu tertentu mengenai agama-agama, sehingga kesatuan transenden tidak dapat disebut sebagai agama melainkan pengalaman keagamaan.

Menurut al-Attas, kita dapat mengenal Tuhan melalui al-Qur'ān di mana di dalamnya telah dijelaskan sifat-sifat serta nama-nama Allah yang baik. Al-Attas membedakan konsep Tuhan sebagai rabb dan Tuhan sebagai iläh. Hal ini sesuai dengan konsep Islam mengenai tauhid yang secara umum terbagi dalam tiga kategori, yakni tauhid rubübiyah, tauhid ulühìah serta tauhid asm $\vec{a}$ dan sifat-sifat Tuhan. Klasifikasi tiga pembagian ini selaras dengan pemikiran Ibn Taymìyah tentang tauhid. Pembagian tauhid menjadi tiga pertama kali

18 Abdul Rahman Haji Abdullah, Pemikiran Islam di Malaysia: Sejarah dan Aliran (Yogyakarta: Gema Insani, 1997), 133.

${ }^{19}$ Ibid., 134.

20 Sayyed Hossein Nasr, Tiga Madz̧ab Utama Filsafat Islam (Yogyakarta: IRCiSoD, 2006), 52. 
dicetuskan oleh Ibn Taymīyah yang kemudian diikuti oleh Muhammad b. 'Abd al-Wahhāb, perintis ajaran Wahabi. ${ }^{21}$

\section{Tauhid Rubūbìyah}

Kata tauhid memiliki arti kata yang berarti keesaan Allah, kepercayaan bahwa Allah hanya satu. Secara etimologis kata tauhid memiliki arti mengesakan. Maksudnya meyakini bahwa Allah adalah Esa, Tunggal atau Satu. Sedangkan Tauhid rubübiyah, adalah meyakini bahwa Tuhan Rabb al-'Álamin, pencipta alam raya adalah satu yakni Allah. Sedangkan kata Rabb (Tuhan) yang digunakan al-Qur'ān memiliki tiga unsur makna, yakni: Yang Menciptakan, Yang Memiliki, dan Yang Mengatur. Dari asal kata Rabb ini kemudian muncul kata rubübīyah. Menurut Muhammad Rashīd Riḍā-sebagaimana yang dikutip oleh Firdaus_-kata rubübiyah memiliki makna pengaturan dan pemeliharaan. $^{22}$

Meyakini Tuhan sebaga rabb berarti meyakini Tuhan sebagai penguasa seluruh alam. Dia adalah pencipta yang menghidupkan dan mematikan, yang menetapkan seluruh aturan dan hukum atas semua makhluk ciptaan-Nya, pemberi rejeki, dan pengatur alam. Tuhan memiliki otoritas absolut tanpa ada yang dapat menghalangi dan menghambat-Nya. Bila Dia berkehendak memberikan manfaat (kebaikan) kepada seseorang, maka tak seorang pun mampu menolaknya. Pun bila Dia berkehendak lain, tak seorang pun dapat menghalangi-Nya. Tidak ada daya menghindari perbuatan dosa kecuali dengan pemeliharaan-Nya, dan tidak ada kekuatan untuk melakukan ketaatan kepada-Nya kecuali dengan pertolongan-Nya. Hal ini sebagaimana yang dijelaskan dalam Q.S. al-An‘ām [6]: 17 dan Q.S. al-Furqān [25]: 2.

Al-Nafasī menjelaskan bahwa ketika seseorang melempar kaca dengan batu hingga pecah, maka lemparan, hantaman batu dan pecahnya kaca tersebut adalah ciptaan Allah. Jadi seorang hamba hanya melakukan kasb dengan mengarahkan niat dan kehendak untuk melakukan suatu perbuatan dan kemudian pada saat itulah Allah menciptakan dan menampakkan perbuatan tersebut.

${ }^{21}$ Muhammad Idrus Romli, Madzhab al-Asy'ari, Benarkah Ablussunnah Wal-Jama'ah? Jawaban Terhadap Alirah Salafi (Surabaya: Khalista, 2009), 224.

${ }_{22}$ Firdaus, "Konsep al-Rububiyah (Ketuhanan) dalam al-Qur'an”, Jurnal Diskursus Islam, Vol. 3. No. 1 (2015), 106. 
Menurut al-Attas, Tuhan dalam Islam adalah Esa dalam sifat dan nama-Nya. Pun Ia Esa dalam eksistensi dan esensi-Nya. Tuhan juga menciptakan semesta melalui ketiadaan, dari yang tiada menjadi ada karena Tuhan menciptakannya dengan ilmu, kehendak, dan kekuasaan-Nya. Proses penciptaan Tuhan bersifat kekal, tetapi konten yang terdapat dalam proses penciptaan Tuhan tidak kekal. Konsep keEsa-an Tuhan ini disebut tauhid. ${ }^{24}$

Mengetahui dan meyakini Tuhan sebagai rabb saja di dalam Islam tidak cukup. Mengetahui Tuhan sebagai rabb dan sebagai iläh adalah berbeda. Jika seseorang hanya mengetahui serta meyakini Tuhan hanya sekadar rabb Sang Maha Pencipta saja bisa disebut kafir. Karena orang-orang kafir pun meyakini akan adanya Tuhan sebagai rabb Sang Pencipta alam semesta beserta isinya. Iblis pun sebagai salah satu makhluk ciptaan-Nya juga mengetahui dan meyakini Tuhan sebagai rabb, Sang Pencipta alam semesta, akan tetapi ia disebut kafir karena menegasikan perintah Tuhan. ${ }^{25}$

Pengetahuan serta keyakinan terhadap Tuhan sebagai rabb harus disertai dengan pengetahuan serta keyakinan terhadap Tuhan sebagai iläh. Dia harus diyakini dan dipatuhi segala perintah-Nya dengan metode dan cara yang ditunjukkan oleh para utusannya. Jika kita meyakini Tuhan sebagai rabb namun mengingkari cara, metode serta jalan dan bentuk yang ditunjukkan oleh-Nya, itu bisa disebut kafir.

\section{Tauhid Ulūhìyah}

Tauhid ulübiyah adalah meyakini Allah adalah satu-satunya Tuhan yang berhak untuk disembah, sebagai tempat tunduk/merendah bagi hamba-Nya dalam beribadah. ${ }^{26}$ Tauhid ulübìyah juga merealisir arti dari kalimat tauhid Là ilāh illā Allah. Para rasul dan Nabi yang diutus oleh Allah selalu mendakwahkan tauhid ulübìyab. ${ }^{27}$

Menurut Ibn Qayyim al-Jawziyah, keyakinan terhadap Tuhan sebagai iläh harus disertai dengan kesempurnaan cinta dan rasa rendah diri. Dengan meyakini tauhid ulühìyah, seseorang harus mengabdikan diri-Nya semata-mata hanya kepada Allah dan tidak menyekutukanNya. Hanya Allah tempat bergantung dan sandaran bagi segala

\footnotetext{
24 Al-Attas, Prolegomena, 13.

${ }^{25}$ Ibid., 8.

${ }^{26}$ Daud Rasyid, Islam dalam Berbagai Dimensi (Jakarta: Gema Insani Press, 1998), 19.

27 Abdullah bin Abdul Muhsin At-Turki, Dasar-dasar Aqidab Para Imam Salaf, terj. Nabhani Idris (Jakarta: Qalam, 1995), 161.
} 
harapan. ${ }^{28}$ Sejalan dengan Ibn Qayyim, Said Aqil Siraj menjelaskan ketika seorang hamba berupaya menyembah dan beribadah kepada Allah secara tulus dan murni serta diiringi perasaan mahabbah, khawf, rajä, dan tawakal, hamba itu telah memasuki wilayah tauhid ulühiyah. ${ }^{29}$

Bagi Al-Attas, meyakini Tuhan sebagai iläh berarti tidak menyekutukan-Nya dan tunduk serta taat kepada-Nya dengan cara, metode serta jalan yang telah ditunjukkan-Nya. ${ }^{30}$ Manusia tidak hanya mengimani atau meyakini Tuhan sebagai Sang Pencipta, Pemberi rejeki saja namun harus disertai juga dengan menyakini, tunduk dan taat kepada Tuhan dan segenap hukum-hukum yang telah ditetapkan Tuhan sebagai cara yang benar untuk beribadah kepada-Nya. Keyakinan terhadap tauhid rubübiyah harus disertai juga dengan tauhid un̄izyah, karena tauhid yang tersebut terakhir ini adalah untuk membedakan orang yang bertauhid murni dengan orang musyrik. Hukum serta metode yang telah ditetapkan Tuhan dapat diketahui melalui ajaran-ajaran para nabi dan rasul-Nya.

\section{Konsep Manusia Menurut Syed Naquib Al-Attas}

\section{Hakikat Manusia}

Manusia adalah makhluk ciptaan Tuhan yang memiliki kelebihan dibandingkan dengan ragam makhluk lainnya. Manusia disebut juga makhluk monodualistik karena memilki hakikat ganda atau dwi hakikat (dual nature), yakni jiwa dan raga, atau jasmani dan ruh sekaligus, sehingga manusia adalah makhluk jasadiah dan rohaniah sekaligus. ${ }^{31}$ Manusia juga disebut makhluk multidimensi. Dimensi pertama, secara fisik manusia memiliki beberapa persamaan dengan hewan, seperti membutuhkan makan, minum dan kawin. Dimensi kedua, manusia memiliki emosi. Dimensi ketiga, manusia memiliki perhatian terhadap keindahan. Dimensi keempat, manusia memiliki naluri untuk menyembah kepada Tuhannya. Dimensi kelima, manusia dikaruniai akal pikiran serta kehendak bebas, sehingga mampu menciptakan keseimbangan dalam kehidupan. Dimensi keenam, manusia memiliki daya kemampuan untuk mengenal dirinya,

\footnotetext{
${ }^{28}$ Muhammad Sa'id al-Qahthani dkk, Memurnikan Laa Ilaaha Illallah, terj. Abu Fahm dan Mohammad Hatta (Depok: Gema Insani, 2006), 19.

29 Said Aqil Siroj, Tasawnf sebagai Kritik Sosial: Mengedepankan Islam sebagai Inspirasi bukan Aspirasi (Bandung: Mizan, 2006), 317.

30 Al-Attas, Prolegomena, 8.

31 Wan Mohd Nor Wan Daud, Filsafat dan Praktik Pendidikan Islam Syed Naquib AlAttas (Bandung: Mizan, 2003), 94.
} 
bagaimana dirinya diciptakan, mengapa dirinya diciptakan dan untuk apa dirinya diciptakan. ${ }^{32}$

Sedangkan menurut beberapa filsuf Barat seperti Max Scheller yang menyebut manusia sebagai Das Kranke Tier, yakni hewan yang sakit dan selalu gelisah. ${ }^{33}$ Manusia disebut juga sebagai homo religious, bomo economicus, homosapiens, manusia arif yang memiliki akal budi yang menjadikannya lebih unggul dari makhluk-makhluk lainnya. Sebutan lainnya untuk manusia adalah homo faber karena manusia mampu menciptakan alat-alat yang dapat digunakan untuk bertahan hidup. Manusia juga disebut sebagai homo economicus dan homo laquen, yakni makhluk yang pandai menciptakan bahasa serta mampu menuangkan pikiran dan perasaan manusia dengan menggunakan kata-kata tertentu. ${ }^{34}$ Di samping itu terdapat pula ungkapan lain yang menyebut manusia sebagai animal rationale (hewan yang rasional atau berpikir), animal symbolicum (hewan yang menggunakan simbol), dan animal educandum (hewan yang bisa dididik). ${ }^{35}$

Al-Attas memaknai hakikat manusia sebagai rational animal yang dalam bahasa Arab disebut bayawān nätiq; makhluk hidup yang berbicara. Al-Attas menginterpretasi kata bayawān sebagai makhluk hidup, bukan hewan. Lafal hayawān berasal dari kata b̧ayy yang memiliki arti sebagai organized being yang memiliki nilai spiritual. Sedangkan kata nätiq berasal dari kata nutq, yang memiliki makna kemampuan jiwa untuk mengenal Tuhan Sang Pencipta, mengenal dirinya sendiri, berbicara, membedakan serta membuat perbedaan untuk merumuskan dan mengomunikasikan arti simbol. ${ }^{36}$ Pemikiran Al-Attas mengenai makna di atas dirujuk dari pemahaman Q.S. alA'rāf [7]: 172.

Al-Attas juga menjelaskan dan menegaskan bahwa pada hakikatnya manusia adalah ciptaan Tuhan yang spesial dan baru. AlAttas menolak definisi manusia menurut klasifikasi para antropolog. ${ }^{37}$

\footnotetext{
32 Achmad Wahyuddin dkk., Penddikan Agama Islam untuk Perguruan Tinggi (Surabaya: Grasindo, 2009), 44.

${ }^{33}$ Drijarkara, Percikan Filsafat (Jakarta: Pembangunan Jakarta, 1981), 140.

${ }^{34}$ K. Bertens, Panorama Filsafat Modern (Jakarta: Teraju, 2005), 1.

35 Siti Khasinah, "Hakikat Manusia Menurut Islam dan Barat", Jurnal Ilmiah Didaktika: Media Ilmiah Pendidikan dan Pengajaran, Vol. 13, No. 2 (2013), 297.

${ }^{36}$ Syed Muhammad Naquib Al-Attas, On Justice and The Nature of Man: A Commentary on Surah Al-Nisa' (4): 58 and Surah Al-Mu'min (23): 12-14 (Malaysia: IBFIM, 2015), 31.

${ }^{37}$ Al-Attas, On Justice, 36.
} 
Baginya, manusia adalah jiwa dan sekaligus jasad, jasmani dan rohani. Sisi jasmani dan indra manusia, mengalami perubahan dan berfungsi untuk memelihara kehidupannya di dalam dunia. Sedangkan dimensi batin manusia memiliki kemampuan untuk merumuskan maknamakna yang melibatkan penilaian, pembedaan dan penjelasan. Keterkaitan manusia dengan jasad dan ruh menjadikan manusia pada satu sisi sebagai jiwa yang tinggi atau rasional (al-nafs al-nätiqah) dan pada sisi lain dianggap sebagai jiwa hewani, jiwa yang rendah (al-nafs al-ḥayawāniyah) ketika berhubungan dengan jasad. ${ }^{38}$ Ada beberapa istilah atau definisi tentang manusia menurut al-Attas. Istilah yang pertama adalah bashar, yang digunakan untuk melihat manusia dari aspek jasmani, bentuk fisik, dan sisi biologisnya. Manusia dilihat dari segi jiwa rasionalnya disebut dengan insan. ${ }^{39}$

Manusia juga memiliki organ kognitif spiritual dan rasional, qalb dan akal. Manusia memiliki daya untuk mendapatkan pengalaman, baik secara jasmani, intelektual maupun spiritual; bahwa manusia memiliki potensi menyimpan pedoman dan kebijaksanaan di dalam dirinya sendiri; dan bahwa ia memiliki kekuasaan serta kemampuan untuk berbuat adil pada dirinya. ${ }^{40}$

Dalam klasifikasi makhluk hidup di alam semesta terdapat tiga kingdom (al-mawlīd al-thaläth), yakni hewan, tumbuhan, dan mineral. Manusia sebagai makhlus monodualistik-yang memiliki sisi fisik sebagai bashar dan sekaligus segi rohani sebagai insan-menganggap dirinya termasuk dalam klasifikasi animal kingdom, karena memandang dirinya sendiri dari aspek biologis adalah sama dengan hewan, hanya berbeda pada derajat saja. Meskipun demikian, menurut Al-Attas, sifat biologis manusia berbeda dengan hewan. Sifat biologis manusia sebagai bashar memiliki hubungan erat dan tidak dapat dipisahkan dengan sifat rohani sebagai insan. Lebih dari itu manusia memiliki klasifikasi kingdom-nya sendiri. Hal ini sebagaimana yang dapat dipahami dari Q.S. al-Baqarah [2]: 186.

Manusia adalah makhluk Allah yang tercipta dengan keistimewaan dari makhluk-makhluk lainnya. Manusia diberi mandat sosial oleh Allah untuk menjadi khalifah di bumi. Oleh sebab itu, Al-Attas berpendapat bahwa benar jika manusia diberikan klasifikasi sendiri

\footnotetext{
38 Ibid., 38.

${ }^{39}$ Ibid., 41.

40 Syed Muhammad Naquib al-Attas, Islam dan Sekularisme (Bandung: PIMPIN, 2011), 177.
} 
yang disebut the kingdom of man, khalifah Allah di bumi. Di dalam the kingdom of man ini tidak ada klasifikasi untuk general, spesies ataupun jenis, hanya ada klasifkasi dalam ras bangsa, suku dan individu. ${ }^{41}$

\section{Kebebasan Manusia}

Pemberian amanah mandat sosial kepada manusia sebagai khalifah Allah di bumi disertai juga dengan potensi-potensi (fitrah) serta ilmu agar manusia mampu mengembangkan dan berbuat demi kesejahteraan serta kemakmuran bumi. Murthada Mutahhari-sebagaimana yang dikutip Mohammad Monib dan Islah Bahrawi-menyatakan bahwa manusia juga diciptakan sebagai makhluk yang bebas dan merdeka, termasuk berkehendak menentukan pilihan. ${ }^{42}$ Sedangkan menurut Nurcholis Madjid manusia memiliki hak dengan kebebasan nuraninya yang dapat digunakan untuk bereksperimen dan melakukan perbuatan baik-buruk, benar-salah. Karena adanya hak kebebasan nurani inilah manusia harus menerima risiko dan diminta pertanggungjawaban atas semua yang dilakukannya. ${ }^{43}$ Hamid Basyaib menyatakan seluruh ajaran dalam Islam selalu mengandung ajaran kebebasan kehendak. Inti dari kebebasan sebenarnya adalah prinsip bahwa manusia merupakan subjek, indvidu yang bertanggung jawab penuh atas drinya. Dalam kebebasan selalu mengandung tanggung jawab. Karena manusia adalah subjek yang sadar dan berkomitmen, maka ia tidak boleh dipaksa. ${ }^{44}$

Muhammad 'Abduh dalam Risālat al-Tawhìd memberikan penjelasan mengenai kehendak bebas manusia dengan mengatakan bahwa hukum alam yang diciptakan oleh Allah mencakup semua makhluk yang sesua dengan sifat dasarnya, dan tak terkecuali manusia. Manusia dicipta sesuai sifat dasar khusus baginya, yakni berpikir dan memilih perbuatan yang sesuai dengan pemikirannya. ${ }^{45}$ Manusia dapat mempertimbangkan baik-buruk serta akibat dari perbuatan yang dilakukannya dengan menggunakan akalnya. Manusia tidak akan

\footnotetext{
41 Al-Attas, On Justice, 41.

42 Mohammad Monib dan Islah Bahrawi, Islam dan Hak Asasi Manusia dalam Pandangan Nurcholis Madjid (Jakarta: Gramedia Pustaka Utama, 2011), 148.

43 Ibid., 147.

${ }^{44}$ Hamid Basyaib, Membela Kebebasan Percakapan tentang Demokrasi Liberal (Tangerang: Pustaka Alvabet, 2006), 225.

45 Muhammad Abduh, Risalab Taubid, terj. K.H. Firdaus (Jakarta: Bulan Bintang, 1992), 49-52.
} 
berbuat sesuatu kecuali setelah mempertimbangkan akibat dari perbuatannya.

Sedikit berbeda dengan pendapat Abduh mengenai kebebasan manusia, al-Attas memberikan penjelasan bahwa ketika manusia menyatakan bahwa dirinya sanggup untuk mengemban amanah mandat sosial yang diberikan kepadanya, maka hal ini telah mengindikasikan bahwa setiap jiwa manusia memilki kebebasan untuk memilih. Bagi al-Attas, kebebasan manusia sejati adalah pencarian manusia terhadap kehidupan beragama yang baik dan benar, dan pencarian ini hanya dapat ditemukan melalui cara kembali ke fitrah, yakni keinginan dan pengetahuan mengenai penyerahan diri kepada Tuhan. Al-Attas memberikan sebuah istilah teologis untuk kata kebebasan yakni, ikhtiar. Ikhtiar memiliki makna yang berbeda dengan ide modern tentang kebebasan. Lafal ikhtiar yang berasal dari kata khayr, yang maknanya adalah baik, yang berarti kata ikhtär adalah memilih sesuatu yang terbaik. Maka ketika manusia memilih sesuatu yang tidak baik, maka pilihan itu bukan benar-benar pilihan, akan tetapi ketakadilan. ${ }^{46}$

Memilih sesuatu yang terbaik adalah kebebasan sejati yang diberkan kepada manusia, akan tetapi walaupun manusia diberikan kemampuan untuk memlih mengikut atau menolak perintah Allah, yakni hukum agama (sharī'ah), manusia tetap tidak dapat menolak kehendak Allah. Al-Attas menilai bahwa kebebasan sejati hanya dapat dicapai ketika manusia memperoleh iluminas spiritual ma'rifah, di mana manusia telah mampu mengesampingkan hawa nafsunya untuk memperoleh jati diri yang lebih tinggi. Kebebasan manusia memiliki batasan, sehingga dalam setiap tingkah laku manusia ada ruang kebebasan manusia dan tetap menyadari adanya relasinya dengan Tuhan, baik sebagai hamba dan sekaligus sebagai khalifah. Dalam pemahaman teologisnya disebut antroposentrisme transenden.

\section{Relasi Tuhan dan Manusia Syed Naquib Al-Attas 1. Manusia sebagai Hamba Allah}

Pandangan mengenai relasi Tuhan dan Manusia dalam pandangan Al-Attas bisa dilihat dari unsur-unsur pandangan tasawuf Al-Attas. Dalam pandangannya, para sufi dapat mewakili prinsip tentang pandangan hubungan Allah dengan alam.

${ }^{46}$ Daud, Filsafat, 102. 
Tujuan awal dari penciptaan dan eksistensi manusia untuk mengabdi kepada Allah. Pengabdian kepada Allah ini disebut dengan ibadah. Kata ibadah memiliki makna yang merujuk kepada segala bentuk perbuatan pengabdian yang dilakukan oleh manusia dengan penuh kesadaran dan keinginan karena Allah semata dan sesuai dengan sharī'ah-Nya, termasuk di dalamnya ibadah wajib. Jika dalam melakukan ibadah manusia dapat mengekang keinginan hewaninya dan menjadikannya tunduk kepada jiwa akalinya, maka seseorang tersebut digambarkan telah mencapai kebebasan dalam arti telah memenuhi tujuan penciptaan dan eksistensinya serta mencapai kedamaian tertinggi, yang di dalam al-Qur'ān disebut dengan al-nafs almutma'innah. ${ }^{47}$

Dalam Islam terdapat tiga level shari ${ }^{-6}$ ah, yang menggambarkan letak level manusia ketika menjalankan shari' ah. Tiga level shari'‘ ah ini adalam Islam, Iman, dan Ihsan. Islam adalah level awal yang diistilahkan sebagai level sharīah. Sedangkan iman adalah level batin yang tidak tampak. Sementara ihsan adalah level spiritual yang merangkum keseluruhan level sebelumnya. Menurut Al-Attas pengamalan shari'sah pada tingkatan ihsan adalah tasawuf the practice of the shari' $a$ h at the station of ihsan. ${ }^{48}$

Ketika seseorang dalam mengamalkan shari'ah telah mencapai pada level tertinggi, yakni ihsan bukan berarti seseorang tersebut meninggalkan level-level sebelumnya. Ketika seseorang dikatakan beriman, bukan berarti seseorang tersebut meninggalkan Islam. Karena iman tanpa Islam adalah tidak mungkin, karena Islam merupakan praktikal dari keimanan. Demikian pula Islam tanpa iman adalah praktik yang tidak bermakna, karena ruh dari keislaman adalah keimanan. Begitu pula ketika seseorang mencapai level ihsan, maka level Islam dan level iman tidak boleh ditinggalkan. Karena fondasi daripada ihsan adalah keislaman dan keimanan. Level ihsan dapat dicapai ketika kedua fondasinya yang keislaman dan keimanan telah kokoh. Seseorang yang mengamalkan sharī'ah dan telah sampai pada level ihsan inilah yang disebut oleh al-Attas sebagai sufi sejati. Karena definisi tasawuf menurut al-Attas adalah mempraktikkan shari`ah pada tingkatan ihsan tanpa meninggalkan keislaman dan keimanan, atau

\footnotetext{
${ }^{47}$ Al-Attas, Islam, 86-87.

48 Syed Muhammad Naquib Al-Attas, The Positive Aspect of Tasawnuf: Preliminary Thought on an Islamic Philosophy of Science (Kuala Lumpur: Islamic Academy of Science, 1981), 1.
} 
dengan kata lain seseorang yang mampu meningkatkan tingkatan amalannya dari level Islam hingga level ihsan dan tidak terjebak dalam ritualitas spiritual yang kosong dengan sharīah. ${ }^{49}$

Ketika para sufi autentik menyampaikan kebenaran, mereka merujuk kepada ilmu yang paling meyakinkan, karena para sufi autentik ini telah memiliki kesadaran spiritual trans-empirik sehingga dapat mengamati secara langsung hakikat dari fenomena-fenomena berbagai yang disebut dengan istilah kathrah (the multiplicity of phenomena) dalam konteks realita yang tunggal dalam konteks yang bermacam-macam. Para sufi intelektual, ${ }^{50}$ tidak pernah mengingkari semua kewujudan yang pertikuler maupun yang plural. Oleh karena itu, mereka mengetahui level-level kewujudan itu serta dengan ilmu yang sejati selalu bersikap adil, dan dapat memposisikan diri dan memperlakukan apa yang diamati sesuai dengan kewajaran. Karena semua yang tampak kepada para sufi yang autentik ini adalah ta'ayyun dan tajallì dari Sang $W$ äjib al-Wujüd Allah melalui jalan spiritual. Inilah yang sebenarnya disebut dengan wahdat al-wujūd oleh para sufi. ${ }^{51}$

Menurut Al-Attas, Pandangan kaum sufi tentang waḥdat al-wujüd telah memperlihatkan sistem metafisik yang benar dan telah merangkum pemikiran ontologis, kosmologis, dan psikologis. Sudut pandang yang sering digunakan oleh al-Attas dalam menjelaskan tentang hubungan antara Pencipta dengan makhluk-Nya adalah pandangan-pandangan Ibn Arabī. Hubungan antara Pencipta dan ciptaan-Nya dikenal dengan istilah tanäzul dan taraqqi. Tanazzul dalam konteks tajalli wa ta'ayyun Sang Pencipta kepada ciptaan-Nya. Sang Pencipta menampakkan diri melalui ayat-ayat-Nya kepada hambanya sesuai level dan martabat sang hamba. Bagi al-Attas, terdapat beberapa tingkatan kewujudan yang berawal dari Wujud Mutlak dan berakhir pada al-wujüd al-mumkin, yakni: kesatuan ilahi (al-wähidìyah), nama-nama dan sifat-sifat (al-asmä' wa al-sifät), arkitep permanen (al-

49 Akhmad Rofii Damyati, "Syed Muhammad Naquib Al-Attas dan Konsep Metafisika dalam Islam”, El-Furqonia, Vol. 1, No. 1 (Agustus 2015), 20-21.

50 Sufi intelektual adalah kalangan spiritualis yang tidak hanya memperhatikan pentingnya ilmu dan hanya menekankan kepada aktivitas rohani tanpa akal, akan tetapi para sufi intelektual mempraktikkan tasawuf dengan ilmu yang agung. Karena kebanyakan sufi yang hanya menekankan kepada aktvitas ruhanyah saja terjebak kepada tarekat dan cenderung mencetak pseudo-sufi atau sufi yang bukan pencari hakikat sebenarnya, sehingga mengabaikan sharīah dan terjebak dalam aktivitas ritual wirid yang berkepanjangan.

${ }^{51}$ Damyati, Syed Mubammad, 22. 
a'yān al-thäbitah), arketip-arketip luar (al-a'yān al-khärijīyab), dan dunia yang tampak ('älam al-shabädab). ${ }^{52}$

Adapun hubungan yang kedua adalah taraqqi, di mana sang hamba kembali kepada Sang Pencipta. Taraqqi adalah upaya seseorang untuk meningkatkan kelmuannya dengan cara ihsan. Ketika manusia telah mencapai derajat yang lebih tinggi dengan cara ihsan, maka ia akan dapat bertemu dengan tajalliyät dan ta'ayyunat Allah. Tajalliyat dan ta'ayyunät Allah tidak tunggal, tapi sebagaimana telah dijelaskan di atas, terdapat setidaknya lima level ta'ayyun yang akan dijumpai seseorang dalam mengenal Sang Khaliq. Ketika seseorang telah sampai pada level tersebut, maka ia akan melihat hakikat segala sesuatu dengan pengamatan langsung dan pencapaian informasi yang lebih akurat. ${ }^{53}$

\section{Manusia sebagai Khalifah Allah di Bumi}

Al-Attas menyebut manusia dengan kata al-insān yang merujuk pada Q.S. Țāhā [20]: 115. Ayat tersebut menjelaskan sifat kealpaan manusia akan tugas dan kewajibannya. Manusia disebut juga insan karena setelah perjanjiannya dengan Allah yang menuntutnya untuk memenuhi perintah dan larangan Allah, ia lupa sehingga menyebabkan keingkaran manusia, dan sifat tercela ini mengarahkan manusia kepada ketidakadilan dan kejahilan.

Meskipun demikian manusia dikaruniai oleh Allah dengan anugerah daya pandangan dan kepahaman yang benar dan kecenderungan menikmati kebenaran sejati serta percakapan dan komunikasi yang benar. Allah juga telah menunjukkan kepada manusia apa yang benar dan apa yang salah sehingga manusia dapat bebas memilih perbuatan mana yang harus diambil agar dapat berjuang mencapai takdirnya yang cerah. ${ }^{54}$

Manusia memiliki kapasitas yang paling tinggi dibandingkan dengan makhluk-makhluk lainnya. Kapasitas tinggi yang dimiliki manusia ini membuat manusia cenderung untuk dekat kepada Tuhan melalui kesadarannya akan kehadiran Tuhan. Manusia juga diberikan kebebasan serta kemerdekaan untuk memilih jalannya masing-masing. Tidak hanya itu manusia juga dikaruniai oleh Tuhan dengan akal, yang dengan akalnya manusia mampu membedakan dan memilih mana

\footnotetext{
52 Al-Attas, Prolegomena, 260, 267-310.

${ }^{53}$ Ibid., 260.

${ }^{54}$ Al-Attas, Islam, 174.
} 
yang baik dan buruk, dan oleh karena adanya akal pula manusia diberi kewajiban untuk bertanggung jawab atas perbuatannya.

Kemampuan daya yang diberikan Allah kepada manusia menjadkan manusia mampu untuk menjadi khalifah Allah di bumi. Dengan menjadi khalifah Allah manusia diberikan kebebasan untuk mengatur apa yang ada di alam semesta ini. Karena Tujuan utama Allah menciptakan alam adalah untuk mewujudkan manusia sempurna. Karena manusia memiliki kemungkinan untuk mengaktualisir sifat-sifat-Nya secara total dan memilki kesiapan yang dibutuhkan dalam rangka menampilkan sifat-sifat-Nya. Oleh karena itulah Allah menjadikan manusia sebagai khalifah di bumi. ${ }^{55}$ Akan tetapi, kebebasan yang diberikan kepada manusia juga dibarengi dengan tanggung jawab akan apa saja yang ia lakukan di dunia. Untuk dapat menjadi khalifah yang sesuai dengan yang diinginkan oleh Allah, manusia harus dapat mengaktualisir sifat-sifat Allah dalam dirinya.

Yang dimaksud dengan Khalifah fi al-ard tidak tepat diartikan sekadar legalitas normatif untuk menjadi landasan sistem politik bernegara. Makna yang diharapkan di sini adalah makna jabatan tertinggi (pemimpin) dalam suatu sistem pemerintahan atau organisasi. Tepatnya, jika makna khalifah di sini diartikan dengan menunjuk seseorang untuk diberi amanah sebagai pemimpin dalam suatu sistem pemerintahan/kelompok.

Menjadi khalifah di bumi merupakan amanat dari Tuhan yang diberikan kepada manusia. Secara langsung, semua aktivitas dalam menjalankan amanah-Nya bernilai ibadah. Manusia tidak perlu memutar otak untuk berbuat atau bertingkah, karena Allah sudah memberikan pedoman al-Qur'ān dan hadìth sebagai petunjuk untuk bertindak dan melakukan yang terbaik dalam menjalankan amanahNya. Hal ini menunjukkan bahwa manusia harus berpedoman kepada sumber utama Islam tersebut sebagai pedoman inti dalam menjalankan roda kepemimpinannya di bumi. Manusia tidak boleh berbuat sesuka hati ataupun sesuai dengan seleranya. Allah sudah menetapkan ragam tugas yang harus dijalankan sebagai menifestasi dari Allah dalam menjalankan amanah tersebut.

Secara garis besar tugas manusia sebaga khalifah di bumi dapat dibagi menjadi tiga bagian:

${ }_{55}$ Muhy al-Dīn b. 'Arabī, al-Futūhāt al-Makekìyah, Vol. 2 (Beirut: Dār al-Ṣadīr, 1911), 290. 
Pertama, tugas manusia sebagai khalifah bagi dirinya sendiri. Manusia sebagai makhluk yang diciptakan oleh Allah tidak akan lepas dari tanggung jawab untuk melakukan yang terbaik, khususnya bagi dirinya sendiri. Dalam perjalanan hidup seorang pemimpin harus bisa menjaga dirinya sendiri sebelum melakukan yang lebih bagi orang lain. Sehingga langkah pertama dalam menjalankan amanah Allah manusia harus memperbaiki, memantaskan dan mempersiapkan dirinya. Secara logis manusia bisa menjalankan amanah jika ia sudah bisa mengontrol diri dan mengusai dirinya sendiri.

Manusia sebagai mahluk yang monodualistik, terdiri jiwa dan raga, memiliki sisi rohani dan jasmani. Salah satu unsur rohani dalam diri manusia adalah akal dan rasa. Akal digunakan untuk berpkir berbagai macam ilmu pengetahuan yang berguna bagi kehidupan manusia. Sedangkan rasa selalu merindukan adanya keindahan, kebenaran, keadilan, rindu akan kebaikan dan nilai-nilai moral. Perasaan kerinduan ini kemudian diisi dengan nilai-nilai seni dan budaya, perasaan rindu akan kemuliaan diisi dengan takwa. Ketika perasaan merasakan rindu kepada kesucian maka hendaknya diisi dengan meninggalkan perbuatan tercela. Inilah contoh-contoh kebutuhan rohani yang harus dipenuhi manusia. Sedangkan kebutuhan jasmani manusia, berupa sandang dan pangan seperti makanan, minuman, pakaian, tempat tinggal, kesehatan dan lain-lainnya. ${ }^{56}$

Kedua, tugas manusia sebagai khalifah bagi dirinya sendiri. Manusia merupakan makhluk sosial, yang selalu membutuhkan sesamanya dalam kehidupan sehari-hari. Allah telah menciptakan manusia dengan berbagai macam suku, budaya, adat-istiadat, bahasa untuk saling bernteraksi, mengenal dan tolong-menolong. Meskipun diciptakan oleh Allah dengan bermacam-macam suku, budaya, adatistiadat dan bahasa, tetapi yang membedakan manusia di mata Allah hanyalah ketakwaannya.

Manusia dengan sesamanya adalah saudara khususnya bagi sesama Muslim. perjanjian antara jiwa dengan Allah lah yang menjadi landasan persaudaraan dalam Islam. Bahkan ikatan persaudaraan tersebut lebih kuat daripada ikatan darah dan pertalian keluarga. Tidak ada yang lebih kuat dari ikatan perjanjian antara jiwa-jiwa manusia dengan Allah, karena jiwa-jiwa manusia yang diikat dengan perjanjian ni mengakui satu sama lain sebagai saudara, sebagai jiwa-jiwa yang

56 Ahmad Azhar Basyir, Falsafah Ibadah dalam Islam (Yogyakarta: Perpustakaan Pusat UII, 1984), 4. 
memilki pertalian. Mereka adalah saudara senasib yang telah bersaudara jauh sebelum mereka dilahirkan ke dunia. ${ }^{57}$

Tugas manusia sebagai khalifah pada masyarakat adalah melindungi rakyatnya dalam menjalankan segala aktivitas serta menjaga keutuhan alam dari kerusakan yang dapat merubah ekosistem yang ada pada tempat tersebut. menjadi khalifah tidak harus menjadi duduk dipemerintahan tapi hidup ditengah masyarakat dengan mengendali dan membangun masyarakat yang cinta damai sudah merupakan upaya menjalankan amanah kekhalifahannya. Sehingga tidak terbatas pada kepimpinanan formal, seperti menjadi salah satu pejabat pemerintahan jadi rakyat biasa pun tugas kepemimpinan tetap menjadi amanahnya.

Ketiga, tugas manusia sebagai khalifah bagi alam semesta. Allah menciptakan alam semesta ini untuk diambil manfaatnya bagi manusia. Manusia dijadikan oleh Allah sebaga khalifah-Nya di bumi, dan memberikan kepada manusia wewenang untuk mengatur dan mengeksplorasi alam semesta dan seisinya. Akan tetapi Allah juga memberikan tanggung jawab kepada manusia untuk senantiasa menjaga kelestarian alam. Dengan mengelolah alam dan isinya berarti manusia telah menggunakan potensinya dengan baik.

Meskipun manusia diberikan wewenang untuk mengeksplorasi alam semesta beserta isinya, bukan berarti manusia dapat semenamena dalam mengelola dan mengeksplorasi alam semesta ini. Dalam interaksinya dengan alam manusia wajib memperhatikan ramburambu yang tertuang dalam al-Qur'ān dan sunnah. Prinsip tawhï, amānah, saläh, rahmah, 'adālah, iqtisād, riłāyah, dan lain-lain merupakan prinsip-prinsip yang seharusnya selalu dipahami dan diterapkan pada diri manusia dalam berinteraksi dengan alam. ${ }^{58}$

Alam merupakan sunnatullah, yang bergerak berdasarkan situas dan kondisi yang ada, misalnya air yang selalu mengalir dari tempat yang lebih tinggi menuju tempat yang lebih rendah, api yang dapat membakar apapun di sekitarnya. Sifat-sifat alam yang seperti itu membutuhkan seorang pengendali. Oleh sebab itu Allah menciptakan manusia dan diberikan amanah kepadanya untuk menjadi wali Allah dalam mengendalikan alam semesta. Sebagai imbalannya manusia dibolehkan untuk memanfaatkan segala yang ada di alam semesta ni

\footnotetext{
${ }^{57}$ Al-Attas, Islam, 91.

58 Lajnah Pentashihan Mushaf al-Qur'an, Pelestarian Lingkungan Hidup: Tafsir alQur'an Tematik, Vol. 5 (Jakarta: Penerbit Aku Bisa, 2012), 8.
} 
untuk mempertahankan hidup dalam menjalankan tugas sebagai khalifah di bumi. ${ }^{59}$

\section{Penutup}

Tuhan dalam Islam adalah Esa, hidup, kekal dan abadi. KeesaaanNya adalah Mutlak, yang kemutlakannya tidak seperti mutlaknya alam semesta. Tuhan juga bersifat transenden dan juga imanen. Al-Attas membedakan konsep Tuhan sebagai rabb dan Tuhan sebagai Ilāh. Hal ini sesuai dengan konsep Islam mengenai Tauhid, yang secara umum terbagai dalam tiga kategori, yakni tauhid rubübìyah, tauhid ulühìyah, serta tauhid asma dan sifat-sifat Tuhan.

Adapun konsep manusia menurut al-Attas adalah jiwa dan sekaligus jasad, jasmani, dan rohani. Sisi jasmani dan indra manusia mengalami perubahan dan berfungsi untuk memelihara kehidupannya di dalam dunia. Sedangkan dimensi batin manusia memiliki kemampuan merumuskan makna-makna yang melibatkan penilaian, pembedaan dan penjelasan. Keterkaitan manusia dengan jasad dan ruh menjadikan manusia pada satu sisi sebagai jiwa yang tinggi atau rasional dan pada sisi lain dianggap sebagai jiwa hewani, jiwa yang rendah ketika berhubungan dengan jasad.

Sedangkan relasi Tuhan dan manusia sebagai makhluknya, jika dilihat dari konsep tauhid ulübiyah dan tauhid rubübiyah akan menghadirkan dua peran manusia, yakni sebagai hamba dan khalifah di bumi. Ketika kita melihat relasi antara Tuhan dan manusia melalui tauhid ulübìyah, maka posisi manusia adalah hamba Allah yang tujuan awal dari penciptaannya untuk mengabdi kepada Allah dengan penuh kesadaran dan keinginan sesuai dengan shari ${ }^{-} a h-N y a$. Manusia juga memiliki peran sebagai khalifah ketika dilihat dari aspek tauhid rubübìah Allah.

\section{Daftar Rujukan}

Abduh, Muhammad. Risalah Taubid, terj. K.H. Firdaus. Jakarta: Bulan Bintang, 1992.

Abdullah, Abdul Rahman Haji. Pemikiran Islam di Malaysia: Sejarah dan Aliran. Yogyakarta: Gema Insani, 1997.

al-Attas, Syed Muhammad Naquib. Islam dan Sekularisme. Bandung: PIMPIN, 2011.

${ }^{59}$ M. Amin Syukur, Menata Hati agar Disayang Allab (Jakarta: Erlangga, 2013), 67-68. 
-----. On Justice and The Nature of Man: A Commentary on Surah Al-Nisa' (4): 58 and Surah Al-Mu'min (23): 12-14. Malaysia: IBFIM, 2015.

----. Prolegomena to the Metaphysic of Islam: An Exposition of the Fundamental Elements of Worldview of Islam. Kuala Lumpur: ISTAC, 1995.

. The Positive Aspect of Tasawnuf: Preliminary Thought on an Islamic Philosophy of Science. Kuala Lumpur: Islamic Academy of Science, 1981.

al-Qahthani, Muhammad Sa'id dkk. Memurnikan Laa Ilaaha Illallah, terj. Abu Fahm dan Mohammad Hatta. Depok: Gema Insani, 2006.

al-Qur'an, Lajnah Pentashihan Mushaf. Pelestarian Lingkungan Hidup: Tafsir al-Qur'an Tematik, Vol. 5. Jakarta: Penerbit Aku Bisa, 2012.

'Arabī, Muhy al-Dīn b. al-Futūḥăt al-Makkeìyah, Vol. 2. Beirut: Dār alȘadìr, 1911.

At-Turki, Abdullah bin Abdul Muhsin. Dasar-dasar Aqidab Para Imam Salaf, terj. Nabhani Idris. Jakarta: Qalam, 1995.

Baharuddin, M. "Konsepsi Ketuhanan Sepanjang Sejarah Manusia", Jurnal al-Adyan, Vol. IX, No. 1, 2014.

Bakhtiar, Amsal. Filsafat Agama: Wisata Pemikiran dan Kepercayaan Manusia. Jakarta: Rajawali Pers, 2009.

Basyaib, Hamid. Membela Kebebasan Percakapan tentang Demokrasi Liberal. Tangerang: Pustaka Alvabet, 2006.

Basyir, Ahmad Azhar. Falsafah Ibadah dalam Islam. Yogyakarta: Perpustakaan Pusat UII, 1984.

Bertens, K. Panorama Filsafat Modern. Jakarta. Teraju. 2005.

Damyati, Akhmad Rofii. "Syed Muhammad Naquib Al-Attas dan Konsep Metafisik dalam Islam", El-Furqonia: Jurnal Ushuluddin dan Ilmu-ilmu Keislaman, Vol. 1, No. 1, 2015.

Daud, Wan Mohd Nor Wan. Filsafat dan Praktik Pendidikan Islam Syed Naquib Al-Attas. Bandung: Mizan, 2003.

Dhavamony, Mariasusai. Fenomenologi Agama. Yogyakarta: Kanisius, 1995.

Drajat, Amroeni. Suharwardi: Kritik Falsafah Paripatetik. Yogyakarta: LKiS, 2005.

Drijarkara. Percikan Filsafat. Jakarta: Pembangunan Jakarta, 1981.

Firdaus. "Konsep al-Rububiyah (Ketuhanan) dalam al-Qur'an", Jurnal Diskursus Islam. Vol. 3. No. 1, 2015. 
Hamaersma, Harry. Pintu Masuk Dunia Filsafat. Yogyakarta: Kanisius, 2008.

Hardjana, A. M. Penghayatan Agama: Yang Otentik dan Tidak Otentik. Yogyakarta: Kanisius, 1993.

Jacobs SJ, Tom. Paham Allah dalam Filsafat, Agama-agama, dan Teologi. Yogyakarta: Kanisius, 2006.

Khasinah, Siti. "Hakikat Manusia Menurut Islam dan Barat", Jurnal Ilmiah Didaktika: Media Ilmiah Pendidikan dan Pengajaran, Vol. 13, No. 2, 2013.

Leahy, Louis. Dunia, Manusia, dan Tuban: Antologi Pencerahan Filsafat dan Teologi. Yogyakarta: Kanisius, 2008.

Monib, Mohammad dan Bahrawi, Islah. Islam dan Hak Asasi Manusia dalam Pandangan Nurcholis Madjid. Jakarta: Gramedia Pustaka Utama, 2011.

Nasr, Sayyed Hossein. Tiga Madz̧ab Utama Filsafat Islam. Yogyakarta: IRCiSoD, 2006.

Rasyid, Daud. Islam dalam Berbagai Dimensi. Jakarta: Gema Insani Press, 1998.

Romli, Muhammad Idrus. Madzhab al-Asy'ari, Benarkah Ablussunnah Wal-Jama'ah? Jawaban Terbadap Alirah Salafi. Surabaya: Khalista, 2009.

Siroj, Said Aqil. Tasanuf sebagai Kritik Sosial: Mengedepankan Islam sebagai Inspirasi bukan Aspirasi. Bandung: Mizan, 2006.

Syukur, M. Amin. Menata Hati agar Disayang Allah. Jakarta: Erlangga, 2013.

Wahyuddin, Achmad dkk. Penddikan Agama Islam untuk Perguruan Tinggi. Surabaya: Grasindo, 2009.

Yuana, Kumara Ari. 100 Tokob Filsuf Barat dari Abad 6 SM-Abad 21 yang Menginspirasi Dunia Bisnis. Yogyakarta: Andi Offset, 2010. 